\title{
PENDEKATAN CULTURE INDEPENDENT UNTUK ANALISIS KOMUNITAS BAKTERI
}

\author{
Oleh \\ Nur Fitriah Afianti ${ }^{1)}$ dan Yeti Darmayati ${ }^{1)}$
}

\begin{abstract}
CULTURE INDEPENDENT APPROACH FOR BACTERIAL COMMUNITY ANALYSIS. Analysis of bacterial community can be through two approaches, through cultivation (culture dependent) and without cultivation (culture independent). Culture dependent approach is conventional method which only covered few bacteria because not all bacteria could be cultured. Culture independent approach with molecular techniques based on DNA communities can provide more information about the structure and diversity of bacteria in nature, both culturable bacteria and unculturable bacteria. 16S rRNA gene is commonly target gene used in bacterial communities analysis. Other specific target genes also being developed for specific groups of bacteria. Several methods are developed for the analysis of molecular markers $16 S$ rRNA or other specific genes, including Denaturing Gradient Gel Electrophoresis (DGGE), Terminal Restriction Fragment Length Polymorphism (TRFLP), and Single Strand Conformation Polymorphism (SSCP).
\end{abstract}

\section{PENDAHULUAN}

Mikroorganisme terutama bakteri memiliki peranan yang cukup penting dalam ekosistem laut, diantaranya adalah sebagai konsumen, pengurai, dan pemelihara siklus biogeokimia. Bakteri yang berperan sebagai konsumen umumnya adalah bakteri heterotrofik yang memakan produsen dan menghuni zona akuatik di bawah area yang intens terkena sinar matahari. Bakteri pengurai umumnya ditemukan di dasar sedimen dan berfungsi melepaskan zat hara dari organisme mati. Bakteri penghuni bawah laut ini umumnya adalah jenis bakteri pengurai anaerobik tetap, atau fakultatif. Mereka sangat berperan dalam memelihara siklus biogeokimia dan memproduksi unsurunsur tertentu seperti ion ammonium, hydrogen sulfat dan gas nitrogen (Black, 2002).

Kemampuan bakteri dalam mengurai berbagai pencemar organik menjadi senyawa yang tidak berbahaya mulai banyak diperhatikan sebagai alat untuk mengolah lingkungan tercemar secara biologis. Hal ini yang menjadi cikal bakal berkembangnya bidang bioremediasi (Philp et al., 2005). Bakteri dapat dimanfaatkan untuk mengatasi pencemaran

\footnotetext{
1) Kelompok Peneliti Mikrobiologi Laut, Pusat Penelitian Oseanografi-LIPI
} 
yang terjadi di laut yang disebabkan oleh tumpahan minyak, cemaran logam berat, pestisida dan berbagai polutan organik lainnya. Umumnya, bakteri yang digunakan dalam proses bioremediasi adalah bakteri indigen yang secara alami ada di lingkungan tersebut.

Bakteri memiliki diversitas yang sangat besar dalam hal jumlah dan susunan materi genetik, yang merupakan bagian terpenting dalam keanekaragaman hayati (Zinger et al., 2011). Oleh karena itu, penting melakukan analisis komunitas bakteri untuk mengetahui peranan dari masing-masing bakteri pada ekosistem dan, melihat pengaruh senyawa kimia atau polutan tertentu terhadap struktur komunitas bakteri indigen di lingkungan (Kostka et al., 2011). Selain bakteri indigen, tidak menutup kemung kinan adanya bakteri eksogen yang secara sengaja dimasukkan untuk mengatasi pencemaran. Dalam hal ini, analisis komunitas bakteri perlu dilakukan untuk memahami perubahan diversitas bakteri target, apakah bersifat dominan atau hilang akibat kompetisi dengan bakteri indigen (Miyasaka et al., 2006). Ada dua pendekatan dalam menganalisis komunitas bakteri pada suatu lingkungan, yaitu pendekatan culture dependent dan culture independent.

\section{PERBEDAAN PENDEKATAN CULTURE INDEPENDENT DAN CULTURE DEPENDENT}

Pendekatan culture dependent melalui kultivasi bakteri penting dilaku- kan untuk memahami dengan pasti potensi dan karakteristik fisiologis dari bakteri. Akan tetapi, pendekatan ini tidak dapat memberikan gambaran secara utuh mengenai komunitas bakteri (Amann et al., 1995; Onstott et al., 1998). Penggunaan teknik kultivasi dalam analisis komunitas bakteri memiliki banyak kekurangan, karena tidak semua jenis bakteri dapat dikultur. Bakteri yang dapat dikultivasi dengan medium pertumbuhan buatan hanya sekitar $1 \%$ dari total jumlah bakteri di alam (La Valley et al., 2009). Oleh sebab itu, identifikasi karakteristik komunitas mikroorganisme seperti bakteri tidak dapat dilakukan hanya dengan menggunakan metode konvensional melalui proses kultivasi.

Salah satu alternatif untuk memprediksi profil komunitas bakteri di alam adalah pendekatan culture independent melalui teknik molekuler secara langsung berdasarkan genotipe dari genom bakteri pada suatu sampel. Metode molekuler berbasis PCR (Polymerase Chain Reaction) dapat digunakan untuk analisis komunitas bakteri baik pada lingkungan perairan laut maupun terestrial (Wakefield \& Gaffney, 2002). Teknik molekuler diketahui efektif mengkarakterisasi keragaman bakteri pada berbagai habitat yang sebelumnya tidak diketahui, seperti pelagis dan daerah laut pesisir (DeLong, 1992; Giovannoni et al., 1990). Dengan teknik ini kita dapat: (1) mengidentifikasi taksa mikroba yang ada di lingkungan saat ini, (2) mengidentifikasi fungsi biokimia terpenting melalui analisis kode gen dan (3) perakitan seluruh genom dari mikroorganisme yang tidak dapat dikulturkan (Taberlet et al., 2012). 


\section{ANALISIS KEANEKARAGAMAN BAKTERI MELALUI PENDEKATAN CULTURE-INDEPENDENT}

Salah satu aplikasi biologi molekuler dalam mendeteksi dan mengidentifikasi karakteristik bakteri adalah analisis marker 16S rRNA (Amann et al., 1995). Beberapa metode dikembangkan untuk melakukan analisis menggunakan penanda molekuler 16S rRNA atau gen spesifik lainnya, diantaranya Denaturing Gradient Gel Electrophoresis (DGGE), Terminal Restriction Fragment Length Polymorphism (TRFLP), dan Single Strand Conformation Polymorphism (SSCP) (Dahllof, 2000; Ikeda et al., 2006; Olsen, 2009).

Analisis komunitas bakteri umumnya dilakukan berdasarkan gen $16 \mathrm{~S}$ rRNA sebagai gen target, karena memiliki informasi filogenetik yang lengkap, prosedur yang mudah, banyaknya informasi sekuen data base yang tersedia dan semua bakteri memiliki gen ini.16S
rRNA merupakan bagian dari subunit kecil molekul ribosom 30S dan memiliki panjang gen sekitar $1500 \mathrm{pb}$ (pasang basa). Gen 16S rRNA merupakan gen esensial yang memiliki laju evolusi yang rendah dan bersifat lestari (Isenbarger, 2008). Pada gen 16S rRNA terdapat daerah conserved dan variable. Daerah conserved merupakan daerah yang urutan sekuen nukleotidanya hampir selalu sama pada setiap jenis bakteri. Keberadaan daerah conserved dimanfaatkan sebagai daerah penempelan primer universal untuk bakteri (Chakravorty et al., 2007). Daerah variable biasa disebut hypervariable regions, memiliki 9 daerah yaitu V1 sampai V9 yang menunjukkan perbedaan sekuen diantara bakteri yang berbeda (Gambar 1) (Huse, 2008). Hypervariable regions dimanfaatkan untuk memprediksi hubungan kekerabatan diantara bakteri pada level genus hingga spesies.Hal ini karena ukuran gen 16S rRNA yang cukup besar sehingga memungkinkan identifikasi hingga ke level spesies (Muyzer \& Smalla, 1998).

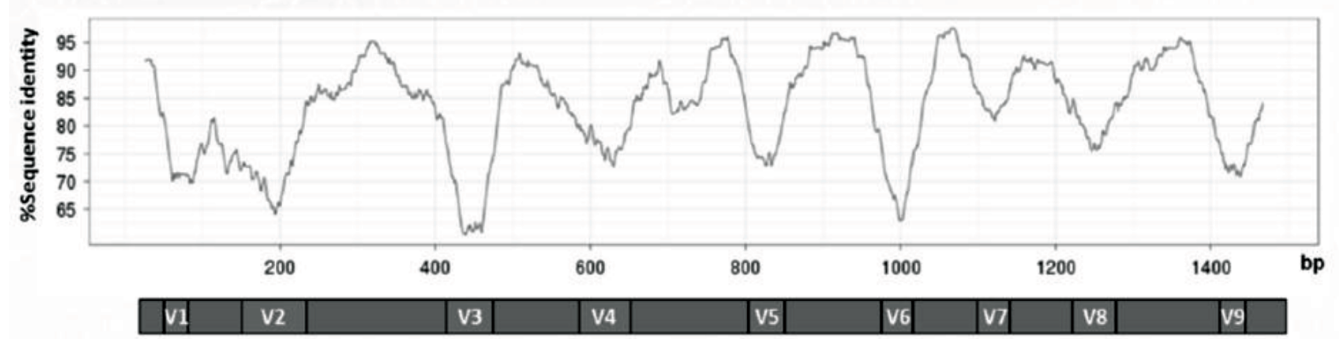

Gambar 1. Daerah Variabel (V1-V9) pada Gen 16S rRNA (Wahl, 2012)

Kelemahan penggunaan gen 16S rRNA adalah keberadaan beberapa spesies bakteri yang memiliki jumlah kopi gen $16 \mathrm{~S}$ rRNA lebih dari satu yang disebut multiple copy number (Dahllof,
2000). Hal ini menyebabkan satu spesies bakteri dapat menghasilkan lebih dari satu pita DNA pada profil. Oleh sebab itu, mulai dikembangkan penggunaan gen target lain yang lebih spesifik dan hanya 
menghasilkan satu kopi DNA, seperti $\sigma$ factor rpoB (Dahloff, 2002), gen hydrogenase, gen pmoA untuk metanogen atau gen dsrAB untuk bakteri pereduksi sulfat.

\section{Denaturing Gradient Gel Electrophore- sis (DGGE)}

DGGE merupakan suatu metode pemisahan fragmen DNA dengan panjang yang sama, namun memiliki perbedaan urutan sekuen nukleotida. Pada awalnya, teknik DGGE dikembangkan untuk mendeteksi terjadinya mutasi titik pada suatu segmen DNA. Akan tetapi, pada perkembangannya, DGGE digunakan untuk mengeksplorasi keanekaragaman mikroba dan analisis struktur komunitas bakteri di alam (Muyzer \& Smalla, 1998).

Pada metode DGGE dilakukan elektroforesis fragmen DNA yang telah terdenaturasi menggunakan dena- turan berupa senyawa kimia yaitu urea dan formamida. Penambahan senyawa kimia berupa formamida dan urea akan menyebabkan denaturasi DNA sehingga mobilisasi fragmen DNA pada gel akrilamid menjadi terhambat. Perbedaan pada urutan sekuens DNA akan menyebabkan banyaknya DNA yang terdenaturasi berbeda-beda, sehingga menentukan laju migrasi fragmen DNA di dalam gel (Maier et al., 2000). Fragmen DNA target diamplifikasi dengan menggunakan primer spesifik yang salah satu primernya mengandung $G C$ clamp, yaitu sekuen nukloeotida yang kaya akan basa GC (Guanine Cytosine) dengan panjang sekitar 30-50 pb. Penambahan GC clamp pada salah satu ujung produk PCR akan meningkatkan sensitivitas, mencegah fully melting dari fragmen DNA, sehingga menghentikan migrasi DNA pada satu tempat di gel akrilamid (Gambar 1) (Muyzer \& Smalla, 1998).
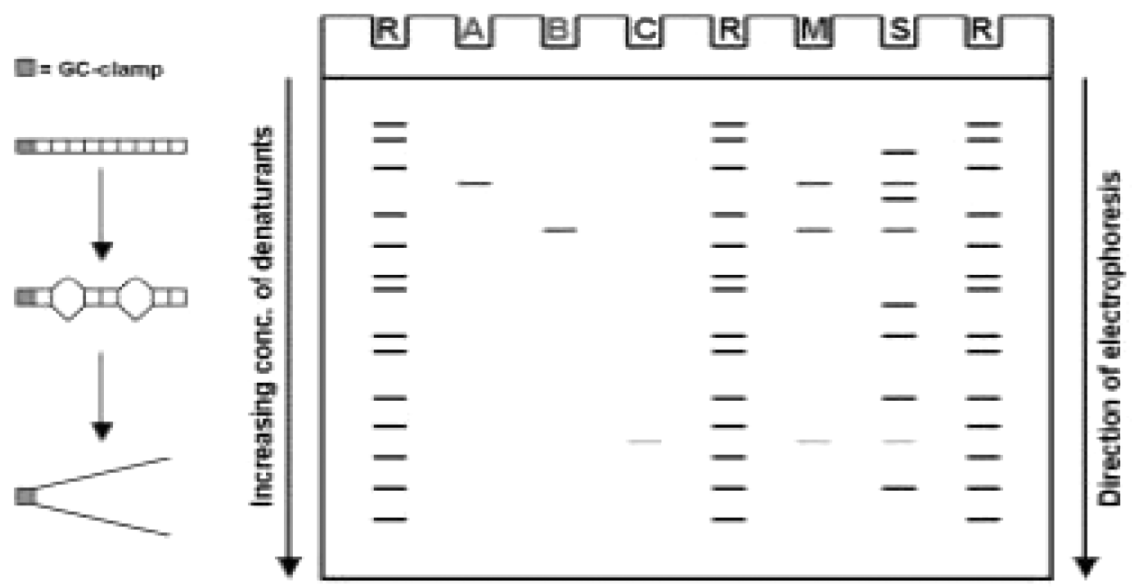

\footnotetext{
$\mathbf{R}=$ Reference pattern, $\mathrm{A}=$ Organism 1, $\mathrm{B}=$ Organism 2, C = Organism 3, $\mathbf{M}=$ Mix of organisms 1,2 and $3,5=$ unknown sample
}

Gambar 2. Prinsip pemisahan DNA pada metode DGGE (Temmerman, 2004) 
Teknik DGGE tidak dapat memisahkan fragmen DNA dengan ukuran yang besar dan hanya efisien memisahkan fragmen dengan ukuran yang relatif kecil, yaitu kurang dari 500 pb. Namun pada ukuran fragmen yang lebih kecil, DGGE dapat mengidentifikasi hingga satu perbedaan basa nukleotida. Proses ini mampu menganalisis beberapa sampel secara bersamaan. Pita pada profil DGGE juga dapat dipotong dan dilakukan reamplifikasi untuk proses sekuensing sehingga dapat dilakukan proses identifikasi bakteri (Smalla et al., 2007). Kekurangan metode DGGE adalah bias pada proses PCR yang dapat menyebabkan kesalahan dalam pembacaan data (Wintzingerode et al., 2000) dan penggunaan kisaran denaturan yang terlalu luas dapat menyebabkan satu pita pada profil DGGE menunjukkan lebih dari satu spesies bakteri (Gelsomino et al., 1999).

\section{Terminal Restriction Fragment Length Polymorphism(TRFLP)}

TRFLP adalah teknik yang di- gunakan untuk mengamati struktur dan dinamika bakteri dengan menggunakan fragmen DNA terfluoresen. Prinsip dari metode ini adalah amplifikasi gen target pada DNA komunitas dengan menggunakan primer spesifik yang salah satunya dilabeli fluoresen TET (4,7,2',7'-tetrakloro-6-karboksiffuoresen) atau 6-FAM (fosforamidit fluorokrom 5-karboksifluoresen) pada ujung 5' sehingga akan dihasilkan amplikon terfluoresen. Selanjutnya digunakan enzim restriksi yang akan memotong amplikon terfluoresen pada daerah pengenalan spesifik. Fragmen DNA hasil pemotongan yang telah memiliki label fluoresen disebut dengan T-RF (Terminal Restriction Fragmen). Fragmen hasil pemotongan enzim restriksi ditentukan panjangnya melalui pemisahan elektroforesis (Egert \& Friedrich, 2003). Setiap bakteri pada sampel memiliki daerah pengenalan spesifik masing-masing sehingga menyebabkan pola pemotongan DNA yang berbeda-beda dan menghasilkan panjang T-RF yang berbeda pula (Gambar 3).
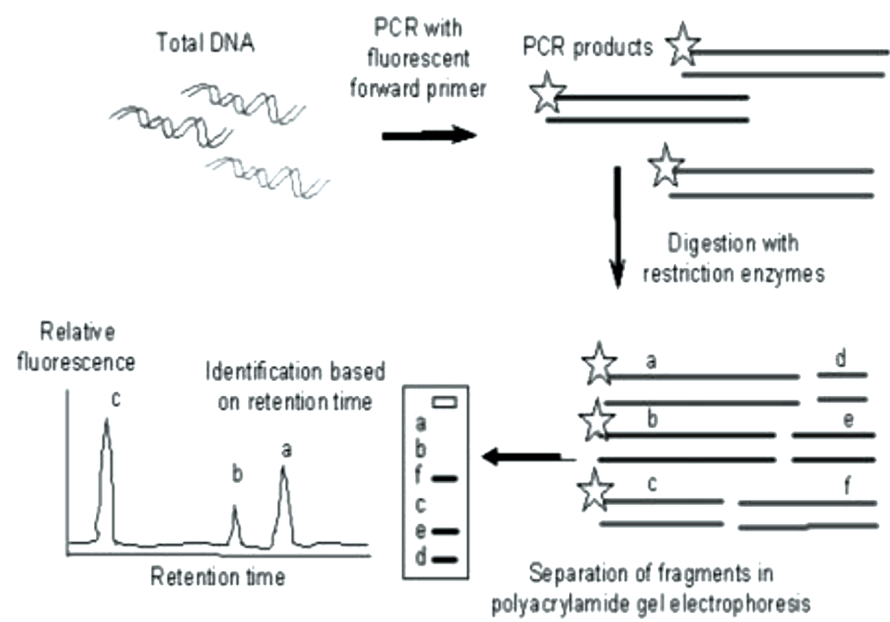

Gambar 3. Tahapan Proses T-RFLP (Kaksonen, 2011) 
Kelebihan TRFLP adalah hasil cepat, relatif konsisten untuk pengggunaan satu enzim restriksi dan lebih sensitif dibandingkan DGGE (Osbornet al., 2000). Seperti pada DGGE, T-RFLP juga menggunakan prinsip PCR sehingga kemungkinan terjadinya bias pada PCR juga dapat menyebabkan kesalahan interpretasi data. Kekurangan dari metode ini adalah kesulitan dalam pemilihan enzim restriksi untuk sekuens baru yang belum diketahui. Penggunaan enzim restriksi yang berbeda juga dapat menghasilkan profil komunitas yang berbeda, sehingga diperlukan perbandingan lebih dari 2 enzim restriksi untuk hasil yang lebih valid (Dunbar et al., 2000). Selain itu, pita DNA pada profil T-RFLP tidak dapat digunakan untuk proses identifikasi seperti halnya DGGE.

\section{Single Strand Conformation Polymor- phism (SSCP)}

Prinsip yang digunakan dalam SSCP adalah perbedaan konformasi untai tunggal DNA dengan panjang fragmen yang sama karena adanya perbedaan basa nukleotida. Pada proses SSCP, gen target diamplifikasi melalui proses PCR kemudian didenaturasi dengan larutan basa menjadi untai tunggal DNA dan dideteksi menggunakan elektroforesis gel akrilamida (Gambar 4).

Mobilitas untai ganda DNA pada gel elektroforesis bergantung pada ukuran dan panjang fragmen namun tidak bergantung pada susunan basa nukleotida. Adapun pada untai tunggal DNA, pergerakannya sangat dipengaruhi oleh sedikit saja perbedaan pada sekuens. Perubahan satu basa nukleotida pada suatu sekuens dapat menyebabkan untai tunggal DNA menjadi tidak stabil, dan terbentuknya struktur sekunder seperti pembentukan loops atau struktur tiga dimensi (Melcher, 2000). Oleh karena itu, untai tunggal DNA akan membentuk struktur yang berbeda bergantung pada urutan sekuen basa nukleotidanya meskipun memiliki panjang fragmen DNA yang sama. Perbedaan konformasi menyebabkan perbedaan laju migrasi fragmen DNA pada elektroforesis gel poliakrilamida (Qian \& Germino, 1999).

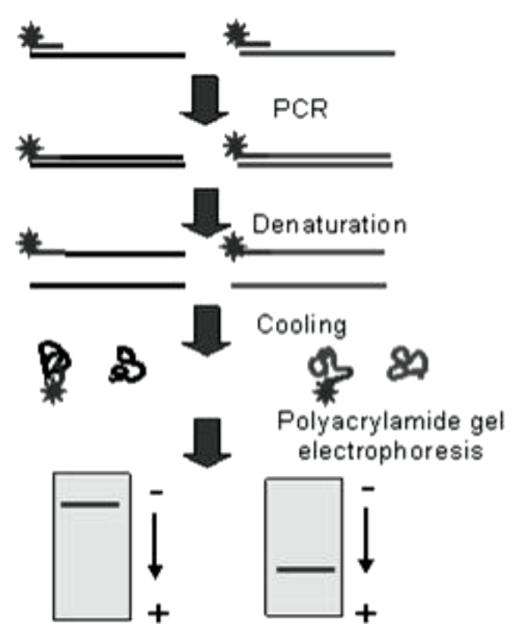

Gambar 4. Prinsip Analisis Single Strand Conformation Polymorphism (Kaksonen, 2011) 
SSCP hanya cocok digunakan untuk memisahkan fragmen DNA yang panjangnya antara $150 \mathrm{pb}$ sampai 400 pb (Muyzer, 1999). Selain itu, satu untai tunggal DNA dapat membentuk lebih dari satu bentuk konformasi yang stabil, sehingga dihasilkan multiple band (Tiedje et al., 1999). Namun, penggunaan metode ini lebih sederhana dibanding DGGE karena tidak membutuhkan primer dengan GC clamp atau denaturing polyacrilamide gel.

\section{PENUTUP}

Keanekaragaman bakteri di laut sangat tinggi, sehingga analisis komunitas bakteri dengan pendekatan molekuler membantu kita mengidentifikasi lebih akurat dan lebih banyak jenis bakteri yang ada di lingkungan, disamping itu dapat digunakan untuk memantau perubahan pada komunitas bakteri tanpa harus melakukan kultivasi. Pada proses bioremediasi laut, pemantauan ini sangat penting karena umumnya proses degradasi polutan dilakukan dalam waktu yang cukup panjang oleh konsorsium bakteri. Peranan masing-masing bakteri bisa jadi berbeda dari waktu ke waktu selama proses tersebut. Hasil analisis komunitas bakteri ini dapat digunakan untuk meningkatkan kemampuan bioremediasi atau bahkan menemukan bakteri dominan yang berperan mengatasi polutan seperti minyak mentah, logam berat, pestisida, dan berbagai polutan organik lainnya.

\section{DAFTAR PUSTAKA}

Amann, R.I., W. Ludwig, and K.H. Schleifer. 1995. Phylogenetic identification and in situ detection of individual microbial cells without cultivation. Microbiol Rev., 59(1):143-69.

Black, J.G. 2002. Microbiology: Principles and Explorations ( $\left.5^{\text {th }} \mathrm{Ed}\right)$. John Wiley \& Sons, Inc.USA. p. 762.

Chakravorty, S., D. Helb, M. Burday, N. Connell, and D. Alland. 2007. A detailed analysis of $16 \mathrm{~S}$ ribosomal RNA gene segments for the diagnosis of pathogenic bacteria. J Microbial Methods, 69(2):330339.

Dahllof, I., H. Baillie, and S. Kjelleberg. 2000.rpoB-based microbial community analysis.avoids limitations inherent in 16S rRNA gene intraspecies heterogenity. Appl Environ Microbiol, 66:33763380 .

DeLong, E.F. 1992. Archaea in coastal marine environments. Proc Natl Acad Sci, 89(12):5685-5689.

Dunbar, J., L.O. Ticknor, and C.R. Kuske. 2000. Assessment of microbial diversity in four southwestern United States soils by $16 \mathrm{~S}$ rRNA gene terminal restriction fragment analysis. Appl Environ Microbiol, 66: 2943-2950. 
Egert, M., and M.W. Friedrich. 2003. Formation of pseudo-terminal restriction fragments, a PCR-related bias affecting terminal restriction fragment length polymorphism analysis of microbial community structure. Appl Environ Microbiol. 69:2555-2562.

Gelsomino, A., A.C. Keijzer-Wolters, G. Cacco, and J. Dirk van Elsas. 1999.Assessment of bacterial community structure in soil by polymerasechain reaction and denaturing gradient gel electrophoresis.J. Microbiol. Methods, 38:1-15.

Giovannoni, S.J., T.B. Britschgi, C.L. Moyer, and K.G. Field. 1990. Genetic diversity in Sargasso Sea bacterioplankton. Nature, 345(6270):60-63.

Huse, S.M., L. Dethlefsen, J. Huber, D.M. Welch, D.A. Relman, and M.L. Sogin. 2008. Exploring Microbial Diversity and Taxonomy Using SSU 63 rRNA Hypervariable Tag Sequencing. PLOS Genetics, 4(11).

Ikeda, S., N. Ytow, H. Ezura,K. Minamisawa, and T. Fujimura. 2006. Soil microbial community analysis in the environmental risk assessment of transgenic plants. Plant Biotechnology, 23: 137-151.

Isenbarger, T.A, C.E. Carr, S.S. Johnson, M. Finney, G.M. Church, W. Gilbert, M.T. Zuber, and G. Ruvkun. 2008. The Most Conserved Genome Segments for
Life Detection on Earth and Other Planets. Orig Life Evol Biosph, 38(6):517-533.

Kaksonen, A. 2011. Molecular approaches for microbial community analysis. http://wiki.biomine. skelleftea.se/biomine/molecular/ index 12.htm diakses tanggal 13 Maret 2015.

Kostka, J.E., O. Prakash, W.A. Overholt, S.J. Green,G. Freyer, A. Canion, J. Delgardio, N. Norton, T.C. Hazen, and M. Huettel. 2011. Hydrocarbon-Degrading Bacteria and the Bacterial Community Response in Gulf of Mexico Beach Sands Impacted by the Deepwater Horizon Oil Spill. Appl. Environ. Microbiol.,77: 227962-227974.

La Valley, K.J., S. Jones, M. Gomez-Chiarri, J. Dealteris, and M. Rice. 2009. Bacterial Community Profiling of the Eastern Oyster (Crassostrea virginica): Comparison of Culture-Dependent and Culture-Independent. Journal of Shellfish Research, 28(4):827-835.

Miyasaka, T., H. Asami, and K. Watanabe. 2006. Impacts of bioremediation schemes on bacterial population in naphthalene-contaminated marine sediments. Biodegradation, 17: 227-235.

Muyzer, G., and K. Smalla. 1998. Application of denaturing gradient gelelectrophoresis (DGGE) and temperature gradient gel electrophoresis (TGGE) in micro- 
bialecology. Anton Leeuw Int $J$, 73:127-141.

Onstott, T.C., T.J. Phelps, F.S. Colwell, D. Ringelberg, D.C. White, and D.R. Boone. 1998. Observations pertaining to the origin and ecology of microorganisms recovered from the deep subsurface of Taylorsville Basin, Virginia. Geomicrobiol J.,15: 353-385.

Osborn, A.M., E.R.B. Moore, and K.N. Timmis. 2000. An evaluation of terminal-restriction fragment length polymorphisms (TRFLP) analysis for the study of microbial community structure and dynamics. Environmental Microbiology, 2: 39- 50.

Philp, J.C., S.M. Bamforth, I. Singleton, and R.M. Atlas. 2005. Environmental pollution \& restoration: a role for bioremediation. In: Atlas R.M. and J. Philp (Eds.)Bioremediation Applied Microbial Solution for Real World Environmental Clean Up. ASM Press, Washington D.C.: 1-48

Qian, F. and G.G. Germino. 1999. Single-strand conformation polymorphism (SSCP) analysis. In: Hildebrandt $\mathrm{F}$ and $\mathrm{P}$. Igarashi (Eds). Techniques in Molecular Medicine. Springer-Verlag, Berlin.

Smalla, K., M. Oros-Sichler, A. Milling, H. Heuer, S. Baumgarte, and R. Becker. 2007. Bacterial diversity of soils assessed by DGGE, T-RFLP and SSCP fingerprints of PCR-amplified 16S rRNA gene fragments: do the different methods provide similar results? Journal of microbiological methods, 69: 470-479.

Taberlet P., E. Coissac, M. Hajibabaei, and L.H. Reiseberg. 2012. Environmental DNA. Molecular Ecology.21:1789-1793

Tiedje, J.M., S. Suming-Brempong, K. Nnsslein, T.L. Marsh, and S.J. Flynn. 1999. Opening the black box of soil microbial diversity. Applied Soil Ecology, 13: 109122.

Wahl,B., F. Ernst, Y. Kumar, B. Muller, K. Stangier, and T. Paprotka. 2012. Defining the microbial composition of environmental samples using next generation sequencing. GATH Biotech.

Wakefield, J.R. and P.M. Gaffney. 2002. mDGGE reveals additional population structure in Eastern Oyster (Crassostrea virginica) populations. J. Shellfish Res. 15:513.

Zinger, L., L.A. Amaral-Zettler, J.A. Fuhrman, M.C. Horner-Devine, and S.M. Huse. 2011. Global Patterns of Bacterial Beta-Diversity in Seafloor and Seawater Ecosystems. PLoS ONE, 6(9): e24570. doi:10.1371/journal. pone. 0024570 